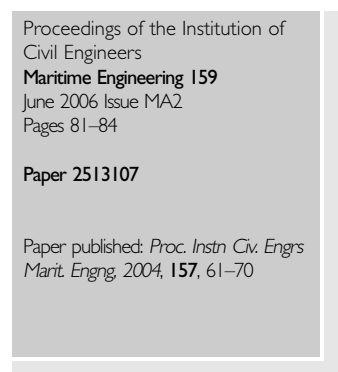

\title{
Discussion: Risk assessment of revetments by Monte Carlo simulation
}

\author{
C. E. Balas, L. Balas and A. T. Williams
}

W. Allsop, HR Wallingford and University of Southampton, UK and F. Buijs, University of Newcastle and HR Wallingford, UK

\section{GENERAL COMMENTS}

The discussers welcome this paper which seeks to demonstrate the use of probabilistic analysis methods in assessment of coastal structures, testing a relatively simple approach against two example rock armoured revetments. The authors note that probabilistic methods can usefully inform decision making in coastal- and flood-defence problems. Such methods utilise existing knowledge about failure processes described by models based on physical processes, while acknowledging uncertainties in input variables and model outputs.

The discussers are concerned that the paper title may lead readers to expect this paper to address the analysis of 'revetments' in general, see, for example, the revetment manual by McConnell, ${ }^{43}$ whereas the methods discussed here are only tested against rock armour. The use of 'risk' in the title also raises expectations that it will include the economic consequences of the revetment failure, instead of which the paper discusses reliability analysis, which is rather different.

The authors demonstrate that limit-state functions are indeed a convenient way to incorporate process-based models in a probabilistic framework. Their aim was then to represent cumulative damage to rock armour with a probabilistic model. They re-cast Hudson's equation ${ }^{44}$ into a limit-state equation, using approaches developed by Melby \&t Kobayashi to incorporate cumulative armour damage. ${ }^{45-48}$ Distribution functions are chosen to represent uncertainties for all variables involved. Finally, the results are compared to information about damage in the past and the conclusions for the decision-making process are presented.

\section{REVETMENT DESIGN AND ANALYSIS METHODS}

The armour stability analysis method used here is the simple Hudson formula, developed for regular waves in deep water and for non-overtopped high-permeability breakwaters. Its use for revetments on low-permeability fill is dangerous as this method would be expected to under-predict stable armour sizes in comparison with those required for armour on low-permeability mounds/embankments. The Hudson formula was also not developed for random waves, so its application to real seas introduces additional uncertainty. The authors would have been much safer using prediction formulae by Van der Meer $^{49,50}$ in which the use of a permeability factor $P=0 \cdot 1$ would give much safer results, and would indicate comparative damage levels.

The weakness of the analysis method used here is extended when considering wave period or steepness, the effects of which are ignored by the Hudson method. For depth-limited conditions, wave steepness values will generally be much lower than those for the unbroken conditions for which Hudson developed his simple equation.

Lastly, the discussers are unaware of any armour stability formula that has been validated for slopes steeper than 1:1.333 (vertical:horizontal). The extrapolation for the Newton revetment of Hudson's method beyond a slope of 1:1 appears most unsafe unless the authors are aware of any such test data.

The reader would be assisted by more complete diagrams of the revetment cross-sections. As the performance of the armouring depends critically on the effective permeability (or otherwise) of the layers beneath the armour, the authors are requested to show layer thickness, placement density and under-layer or filter sizes/grading limits.

The authors note that depth-limited waves are strongly influenced by water level, but give no clear indication of how they computed incident wave conditions at the revetment. The discussers particularly note the steep approach beach at the Newton revetment which may cause substantial shoaling, increasing local wave heights (see examples ${ }^{51,52}$ ). The authors are asked to describe their approach to the derivation of incident waves at the structures and to comment on the relationship of inshore waves with offshore wave height and period, bed slope, and water depth.

\section{PROBABILISTIC APPROACH}

Hudson's equation, although subject to the limitations above, is represented in a limit-state function according to established approaches. The paper would have benefited here from a more comprehensive description of how cumulative damage was 
included in the probabilistic model. The discussers note the choice to use a Monte Carlo calculation for the hydraulic climate combined with separate second-order reliability method calculations for the probability of revetment failure. This separation seems generally sensible to accommodate damage accumulation calculations given different sequences of storms, and the likelihood of those different sequences. Then again, unfortunately only a small paragraph is devoted to this problem, which makes insight into the applied method very hard. Could the authors describe more completely the period over which damage is accumulated, and how they deal with previous levels of damage?

Statistics of hydraulic boundary conditions seem to be well taken care of, but information about strength variables, for example, armour $D_{50}$, is less abundant. That is demonstrated in the paper by the difficulty in establishing distribution functions to represent strength variables. In some cases the literature suggests distribution functions for certain strength variables. In other cases, normal or log-normal distribution functions correspond well with expert judgement. The real distributions or statistics will however only be known by collecting data for which resources are seldom made available.

A final remark is made with regard to how the results can be used to inform decisions (it is recognised that the paper does not intend to go into the total decision-making problem). The paper focuses on how to use the results in the light of exceeding damage thresholds. An advantage of probabilistic methods is that they map revetment quality at different locations to a comparable measure. Replenishment strategies can therefore be optimised in a risk-based approach. The replenishments are then targeted to the locations that are expected to contribute most to the magnitude of the consequences of revetment failure.

\section{OVERALL}

Probabilistic approaches support a more holistic representation of reality by taking into account realistic presentations of physical processes as well as the uncertainties involved. In doing so, the application of these approaches adds an extra dimension to the challenging problem of correctly representing failure processes with conventional engineering models. In this light, the authors have succeeded in basing their approach on established probabilistic concepts. Feedback to decision-making about revetment refurbishment is however weakened by two drawbacks.

First, Hudson's equation has little utility in comparison with Van der Meer's equations for analysis of the stability of rock armouring, especially on low-permeability construction where Hudson's method will give unsafe results. This is compounded in this paper by use of a revetment example that falls outside the valid range for either analysis method.

Second, a more complete description of the incorporation of cumulative damage would have supported more conclusive insights on the validity of the results.

Finally, even though the total decision-making problem is not the focus of the paper, it is worth commenting that risk-based concepts would aid decision making even more than probabilistic concepts alone.

\section{Authors' reply}

The main issues stated by the discussers are addressed in the following paragraphs.

(a) The paper deals with the 'assessment of risk that a system is incapable of meeting the demand which is characterised as the probability of failure over the specified system lifetime under specified operating conditions'. ${ }^{53}$ In the synopsis of the paper it is clearly stated that the paper was concerned with risk assessment (defined above) by interrelating the second-order reliability method (SORM) and the conditional expectation Monte Carlo (CEMC) simulation in order to analyse the safety of Brean and Newton revetments on the south and north coasts of the Inner Bristol Channel, South Wales, UK.

(b) The Environment Agency of the UK carried out the design and construction of Brean and Newton revetments on the south and north coasts of the Inner Bristol Channel, using the deterministic approach in which Hudson's equation was utilised. The safety of these two revetments was assessed by the application of the new reliability model developed in this study, which used the Hudson performance function in order to compare the deterministic and reliability-based studies and to be consistent in these comparisons. Hudson's equation has been verified in large- and small-scale model tests conducted under the attack of both monochromatic and irregular waves, and a large variety of prototype conditions. In the model test executed with irregular waves, the significant wave height ( $H_{\mathrm{s}}$ or $H_{1 / 3}$ ), which is defined as the average of the highest one-third of all waves, has generally been accepted as the design wave height in Hudson's equation. ${ }^{54}$ Using the data for rough quarry stone, Hudson's equation was transformed by Van der Meer into an expression that takes into account the damage levels. The transformed Hudson equation also represents the average of the results of extensive hydraulic model testing (based on $H_{\mathrm{s}}$ ) obtained by Van der Meer, ${ }^{55}$ including depth-limited conditions. The variation in design parameters was given by a comparison of the model test data with the results, and the $\beta$-distributed random variable $Y$ (which is lumped with the resistance components of the failure function) was assigned to the performance function $g$.

(c) The new methodology introduced in the paper is a general method and can be applied to both revetments and rubble mound breakwaters by using the performance functions of Hudson and/or Van der Meer. The authors have already compared these two performance functions in their papers $^{56,57}$ and concluded that including more design parameters with inherent uncertainties gave a larger scatter around the mean value of the Van der Meer performance functions, but more reliable design results. The new methodology of Monte Carlo-SORM introduced in the paper and the computer program developed are able to carry out the design or risk assessment study by using the performance functions of both Hudson and Van der Meer. The new risk model can also be applied to other types of revetments or breakwaters ${ }^{58}$ in general, by incorporating appropriate failure functions. The aim of this paper was clearly to demonstrate the main idea and principles of the new model and apply it to a case study. 
(d) For life-cycle damage estimation, a computational approach was used. In this approach, the annual damage that occurred in the revetment was stored in the computer by considering the return period of the generated design wave height. ${ }^{59}$ In other words, the damage was accumulated in the computer for simulation of damage progression in time as a function of the probability of occurrence of loading in the life cycle, and the temporal variation in the mean damage was corrected for each epoch by using equation (14) of Melby and Kobayashi. ${ }^{54,60}$ This is an approximate method in discrete simulation to determine the time accumulation of damage ${ }^{61}$ when there is a dominating variability of the load variables and it is similar to methods described by Burcharth. ${ }^{62}$

(e) In the paper, the structural safety was evaluated at the limit state, by modelling random resistance (strength) variables with $\beta$ probability distributions, obtained by uncertainty analysis. ${ }^{63}$ The distributions of variation in strength parameters, for example armour $D_{50}$, were obtained from underwater investigations of existing breakwaters, such as the study carried out by Özhan and Yalciner. ${ }^{64}$

( $f$ ) In the CEMC simulation, storm surge and wave height were generated as correlated random variables with probability distributions describing the phenomena. The safety of revetments was evaluated by considering various environmental loading conditions, such as a large statistical variation of tidal range, storm surge and wave data. As the variations inherent in such design parameters were extensive it was suggested that Monte Carlo simulations interrelated with the second-order reliability method (SORM) should be used to determine the safety of revetments. It is a common advantage of reliability-based approaches that the incident wave conditions at the revetment, including shoaling, and the permeability of the structure are simulated for 30000 loading possibilities by probability distributions covering a wide range of local wave heights and permeability conditions $(P)$, in spite of the deterministic design, in which the wave height and permeability factor $P$ are assigned as a single numerical value as indicated by the discussers.

In general, the discussers address the following important comments: 'Reliability-based risk assessment models have the advantage of robustness, provided that the probability distributions of random variables and their correlation are determined from the data compiled over a sufficient number of years. The reliability of coastal structures is highly variable and depends upon the unpredictable nature of coastal storms, the reliability method, and distributions utilised in the design. ${ }^{56}$ As a result, the probabilistic and risk-based approaches work together to assist decision-making.

\section{REFERENCES}

43. McConnell K. J. Revetment Systems Against Wave Attack: a Design Manual. Thomas Telford, London, 1998.

44. Hudson R. Y. Design of Quarry-stone Cover Layers of Rubble Mound Breakwaters, Hydraulic Laboratory Investigation. Waterways Experiment Station, Vicksburg, 1958, Research Report 2-2.

45. Melby J. A. and Kobayashi N. K. Damage progression on breakwaters. In Proceedings of the 26th International
Conference on Coastal Engineering, Copenhagen, Denmark. American Society of Civil Engineers, New York, 1998, vol. 2, pp. 1884-1897.

46. Melby J. A. and Kobayashi N. K. Progression and variability of damage on rubble mound breakwaters. Proceedings of the ASCE, Journal of the Waterway, Port, Coastal and Ocean Division, 1998, 124, No. 6, 286-294.

47. Melby J. A. and Kobayashi N. K. Damage progression and variability on breakwater trunks. In Proceedings of Coastal Structures '99, Santander, Spain. Balkema, Rotterdam, 1999, vol. 1, pp. 309-317.

48. Melby J. A. and Kobayashi N. K. Damage development on stone-armored rubble mounds. In Proceedings of the 27th International Conference on Coastal Engineering, Sydney, Australia. American Society of Civil Engineers, Reston, VA, 2000, vol. 2, pp. 1571-1584.

49. VAn DeR Meer J. W. Rock Slopes and Gravel Beaches under Wave Attack. PhD thesis, Delft University of Technology, April 1988. Also available as Delft Hydraulics Communication No. 396.

50. VAn der Meer J. W. A review of stability formulae for rock and rip-rap slopes under wave attack. In River, Coastal and Shoreline Protection: Erosion Control using Rip-rap and Armourstone (Thorne C. R., Abt S. R., Barends F. B. J., Maynord S. T. and PilarczyK K. W. (eds)). Wiley, Chichester, 1995, pp. 191-212, ch. 13.

51. Allsop N. W. H., Lihrmann H. and Netherstreet I. Wave breaking on/over steep slopes. In Proceedings of Breakwaters, Coastal Structures and Coastlines, ICE. Thomas Telford, London, 2002, Paper 16a.

52. Allsop N. W. H., DuRAnd N. and HuRdle D. P. Influence of steep seabed slopes on breaking waves for structure design. In Proceedings of the 26th International Conference on Coastal Engineering, Copenhagen, Denmark. American Society of Civil Engineers, New York, 1998, pp. 906-919.

53. Kottegoda N. T. and Rosso R. Statistics, Probability and Reliability for Civil and Environmental Engineers, Civil Engineering Series. McGraw-Hill International Editions, Singapore, 1998.

54. Department of the Army. Coastal Engineering Manual. Waterways Experiment Station, Corps of Engineers, Coastal Engineering Research Center, US Government Printing Office, Washington, DC, USA, 2003.

55. VAN DER MEer J. W. Rock Slopes and Gravel Beaches under Wave Attack. Delft Hydraulics Publications, Delft, 1998, Delft Hydraulics Communication 396, pp. 49-95.

56. Balas C. E. and Ergin A. Reliability-based risk assessment in coastal projects: case study in Turkey. Journal of Waterway, Port, Coastal and Ocean Engineering, 2002, 128, No. 2, 52-61.

57. ERgin A. and Balas C. E. Reliability-based risk assessment of rubble mound breakwaters under tsunami attack. Journal of Coastal Research, 2002, SI 36, 266-272.

58. BALAS C. E. and Koç L. Risk assessment of vertical breakwaters-a case study in Turkey. China Ocean Engineering, 2002, 16, No. 1, 123-134.

59. BALAS C. E. and BALAS L. Risk assessment of some revetments in southwest Wales, United Kingdom. Journal of Waterway, Port, Coastal and Ocean Engineering, 2002, 128, No. 5, 216-223.

60. Melby J. A. and Kobayashi N. Progression and variability of damage on rubble mound breakwaters. Journal of Waterway, Port, Coastal and Ocean Engineering, 1999, 124, No. 6, 286-294. 
61. Madsen H. 0., Krenk S. and Lind N. C. Methods of Structural Safety. Prentice Hall, New Jersey, 1986, International Series in Civil Engineering and Engineering Mechanics.

62. Burcharth H. F. Reliability evaluation of a structure at sea, design and reliability of coastal structures. In Proceedings of the 23rd International Conference on Coastal Engineering, Venice, Italy (LAmberti A. (ed.)). American Society of Civil Engineers, New York, 1992, pp. 511-545.
63. Balas C. E. and ERgin A. A sensitivity study for the second-order, reliability-based design model of rubble mound breakwaters. Coastal Engineering Journal, 2000, 42, No. 1, 57-86.

64. Ozhan E. and Yalciner A. C. Determination of Existing Situation in TEAS Akkuyu Harbor Breakwater Construction. Coastal Engineering Research Center, Civil Engineering Department, Middle East Technical University, Ankara, Turkey, 1995, Technical Report No. 52, pp. 1-73.

\section{What do you think?}

To comment on this paper, please email up to 500 words to the editor at journals@ice.org.uk

Proceedings journals rely entirely on contributions sent in by civil engineers and related professionals, academics and students. Papers should be 2000-5000 words long, with adequate illustrations and references. Please visit www.thomastelford.com/journals for author guidelines and further details. 